\title{
WHO urges countries in dengue belt to look out for Zika
}

\author{
Anne Gulland
}

London

Countries where dengue fever is endemic are being urged to be on the alert for cases of the Zika virus, after concern over its spread throughout the Americas and its links to an increase in the number of cases of microcephaly in newborn children. ${ }^{1-5}$

In a briefing to journalists, Bruce Aylward, assistant director general at the World Health Organization, said that any country in the dengue belt that has the Aedes aegypti mosquito- the vector for both dengue and the Zika virus-should be on the lookout for the spread of the disease.

"The issue right now is that countries should be looking at whether there is Zika and if there is whether there's any capacity to detect a change in neurological conditions," he said.

More than a third of the world's population lives in countries where the dengue virus is endemic. The dengue belt covers Central America, most of South America, sub-Saharan Africa, India, and South East Asia.

WHO's director general, Margaret Chan, has convened a meeting of the International Health Regulations Emergency Committee on 1 February to work out whether the outbreak constitutes a public health emergency of international concern. She said that WHO was "deeply concerned" about the spread of the virus in the Americas, the lack of population immunity, and the absence of vaccines, treatments, and rapid diagnostic tests.

She said that the virus had gone from being a mild threat to one of "alarming proportions." She added, "Conditions associated with this year's El Niño weather pattern are expected to increase mosquito populations greatly in many areas."

The virus was first reported in May 2015 in Brazil and since then has spread to 21 other countries in the region. The virus, particularly in Brazil, has been associated with a steep increase in the number of babies born with microcephaly and an increase in the number of cases of Guillain-Barré syndrome. Around 4000 babies have been born with microcephaly since last October, a 20-fold increase on the number of cases occurring between 2010 and 2014. A causal relation between the virus and birth defects and neurological syndromes has not been established but is strongly suspected, said WHO.

Sylvain Aldighieri, unit chief at the Pan-American Health Organization, told journalists that there could be four million cases of the virus in the Americas over the next 12 months. The virus causes a rash, mild fever, and conjunctivitis. Seventy five per cent of people infected are either asymptomatic or have such mild symptoms that they do not present to health services.

Confirming a link between Zika and microcephaly is a challenge, as it is not always possible to detect antibodies in the blood of someone who has been infected with the virus, Aldighieri said. He said, "We have a good laboratory platform to confirm [the virus] during the acute phase, when the patient has fever, rash, and conjunctivitis. We don't have good laboratory tools to confirm what happens the [other] months, because Zika virus has a cross relation with dengue $1,2,3$, and 4 and with yellow fever and West Nile virus."

Aylward added, "There's still a lot of uncertainty as to the association [between Zika and microcephaly]. There are places, such as Colombia, where we haven't seen an association, and it could be a co-infection with another circulating virus."

He said that WHO was unlikely to advise women in the Americas to avoid becoming pregnant as that was a personal decision. But the organisation was keen to ensure that countries were not implementing any "inappropriate measures or advice."

thebmj.com Sixty seconds on ... Zika virus (doi:10.1136/bmj.i467)

McCarthy M. Zika virus outbreak prompts US to issue travel alert to pregnant women. BMJ 2016;352:i306.

2 Dyer O. Zika virus spreads across Americas as concerns mount over birth defects. BMJ 2015;351:h6983.

3 Torjesen I. Zika virus outbreaks prompt warnings to pregnant women. BMJ 2016;352:1500 4 Dyer O. Jamaica advises women to avoid pregnancy as Zika virus approaches. BMJ 2016;352:i383.

5 McCarthy M. First US case of Zika virus infection is identified in Texas. BMJ 2016;352:i212.

Cite this as: BMJ 2016;352:1595

๑ B BMJ Publishing Group Ltd 2016 